\title{
Food Ration and Mental Training for the Improvement of the Free Throw Performance in Congolese Beginners Basketball Players
}

Bouhika Eddie Janvier ${ }^{1}$, Moussouami Simplice Innocent ${ }^{1}$, Tsiama Portejoie Jean Aimé ${ }^{4}$, Bazaba Kayilou Jean Michel ${ }^{1}$, Moyen Rachel ${ }^{5}$, Mizere Moungondo Martin ${ }^{2}$, Maouene Michel ${ }^{3}$, Mbemba François ${ }^{1}$

${ }^{1}$ Laboratoire de nutrition, santé et motricité humaine; Institut Supérieur d' Education Physique et Sportive, Université Marien NGOUABI; BP: 69, Congo-Brazzaville, Congo

${ }^{2}$ Fédération congolaise de Basketball, Congo Brazzaville, Congo

${ }^{3}$ Ministère de la population et de la santé, Congo Brazzaville, Congo

${ }^{4}$ Laboratoire de Psychologie du Sport, Institut Supérieur d'Education Physique et Sportive, Université Marien NGOUABI, BP 100, Brazzaville (CONGO), Congo

${ }^{5}$ Pôle d'excellence de l'AUF; Formation Doctorale transformation alimentaire des agro ressources T2A, Faculté des sciences et techniques de l'université Marien NGOUABI, Congo

Correspondence: Eddie Janvier Bouhika, Higher Institute of Physical Education and sport (ISEPS), Marien NGOUABI University, Brazzaville, Congo.

Received: July 28, 2016 Accepted: August 9, $2016 \quad$ Online Published: October 6, 2016

doi:10.11114/jets.v4i11.1912 URL: http://dx.doi.org/10.11114/jets.v4i11.1912

\begin{abstract}
Objective: Through an experimental study, the present work aims at testing the effectiveness of diet and mental imagery on the success of free throw in Congolese beginners Basketball Players.
\end{abstract}

Method: 45 players participated in this experimental study in Brazzaville (Congo) .These subjects were divided into 3 groups. Group I $(\mathrm{n}=15)$, made up of beginner Basketball players subjected to a balanced diet to the mental training and to the practice of throwing on the ground. Group II $(n=15)$, made up of beginner basketball players from a local team subjected to mental training of the throw and food monitoring; Group III $(n=15)$, beginner Basketball Players participating in the district competitions. The variables studied were: flexion of the legs (FL), body orientation (BO), the extension of the arms (EA), and the success of shots (SS).

Results: The results indicate that the best progress was made by the players in Group I: $+67.7 \%$ for the squat, $+38 \%$ for the orientation of the body, $+45.7 \%$ for the extension of arm, and $83.7 \%$ for successful shots.

Conclusion: In summary, mental rehearsal combined with a balanced diet facilitates the practice of physical and sporting activity and significantly improves learning and performance of athletes.

Keywords: food ration, mental training, learning, free throw, basketball, Congo

\section{Introduction}

There is in any individual who practices physical and sporting activity a tendency to seek for efficiency and therefore a need for performance.

From the literature, it appears that sporting success is linked to the development of physiological abilities, balanced diet that meets the standards of modern dietetics (BintouCoulibaly, 2007) (COUTURE, 2013) but also to the acquisition of very specific psychological skills (Rejeski and Brawley, 1983. Ryan and Lackie 1986; Thill and Mouanda- Mpassi, 1988; Vallerand and Thill, 1993; Deci\& Ryan, 1980; CorbillonetFournier, 2000).

The mental training helps, in this context, the athlete to prepare himself for the action to regulate his activation level and anticipate success (SMIDT 1993). Diet is the action of consuming food for the living organism to function (SANKALE Marc and all, 1974; TRAORECouba, 2006).

Studies have demonstrated, since the advent of sports medicine, that the diet is a solidly built area of athletic preparation and is part of the sporting life of which it determines the progress as well as mental and physical training (Coulibaly, 2004). 
According to The findings of these studies, tangible progress on the development of motor skills and improved performance have been noticed after a training program and reliable sports nutrition.

And yet, the Congo (Brazzaville) is distinguished in the sports field by a large delay in the appropriate use of psychological knowledge applied to sport and sport nutrition. Hence the lack of knowledge or ignorance of factors "motors" or relevant leading to the achievement of results of athletes.

Thus, teachers of Physical Education or coaches forget, if not neglect this dimension.

The fundamental question that we can then ask is whether the diet coupled with the mental training in the Congolese context can be an effective way to improve performance.

The aim of this work is to verify the influence of diet and a sports training based on mental rehearsal strategy among Congolese beginners of basketball players in learning or practicing free throw.

\section{Material and Method}

The materials used for our work were the following:

- A square: vertical ruler graduated from $0 \mathrm{~cm}$ to $200 \mathrm{~cm}$, along which slides a cursor to measure the size of the athletes;

- The survey forms;

- The pens and- pencil eraser;

- A bathroom scales to assess the weight of the athletes; the mass branded athletes QF-2003A, graduated from zero to one hundred eighty kilogram ( 0 to $180 \mathrm{Kg}$ ); a table of FAO Food for the Africa use.

- Congolese and Western food

- The food classification table according to their nutritional value for FAO (Food and Agriculture Organization of the United Nations).

\subsection{Methodology}

The study was conducted in Brazzaville from 10 April to 10 May 2016, a period of one month. It was attended by 45 Basketball Players of three (03) teams playing in the city of Brazzaville

Their mean age was $15.6 \pm 1.4$ years, with extremes of 14 and 17 years. The average duration of practice within their teams was 8 months. These subjects were divided into three (03) experimental groups corresponding to 03 teams.

Group I consisted of 15 players subjected to a diet proposed by a dietician and mental training to practice free throw. This was characterized by the mental repetition of the movement of free throw respecting the different variables used.

Group II consisted of 15 players submitted to the mental training and a food program proposed by the dietician, while Group III consisted of 15 players involved in the competitions of the city but not subject to a mental workout or a food program.

However players from Group I and II also participated in various competitions. The training itself was distinguished by the following sequences: for Group I: mental rehearsal practice that lasted 45 minutes, in this strategy, the athlete should have a look on his thoughts or his mind trying to make a free throw, soon after this mental rehearsal phase, the players went to the practice session of the free throw. This technical and tactical training was to perform the throws respecting the variables defined by the experimenter. Before all sessions, these players ate meals consisting of meat, fish, eggs as animal proteins, and more starchy food such as vegetable proteins that are the basis for the production of proteins (MAUGHAN, 1999).

Similarly, the consumption of food like fruits, sugary drinks, pasta, bread, rice, potatoes that are considered unique fuel for the muscles and the basis for the production of carbohydrates (TRAORE YACOUBA SALIOU , 2006); not to mention the cream consumption, cheese, pastries, meats and nuts as foundations lipids (BURKEL.M, 1995). These meals were divided into breakfast in the morning, lunch at noon and dinner in the evening after practice. A series of drink consists of water, pineapple juice, papaya juice, orange, mango and apple accompanied the meal. The duration of this practice was 3 hours and 02 sessions per week.

For group II, the mental training was held for 2 hours, or 2 sessions per week depending on the day of rest granted by their respective coaches. These players enjoyed the food conditions and mental practices equal to those of Group I.

Regarding the players in the group III, they form the control group because they were not subject to this learning free throw but were doomed to the activities of their coach.

However, for groups subjected to learning the free throw, the variables studied were flexion of the legs, body orientation, the extension of the arms and the success of shots. 
For the assessment of performances, recorded before and after the learning cycle, the scale used was that of Chevalier (1989).

For the analysis of eating habits, we offered food to groups I and II, during breakfast, lunch and dinner each day when training sessions were conducted.

\subsection{Statistical Analysis}

Concerning the collection and statistical analysis of data during the experiment, the actual performance were collected individually and in groups averaged. They were the samples of the scores of data. Statements scores spread before and after the cycle has been analyzed from the Student $t$ test. To examine the perceived differences between the 3 groups and the effect of learning methods used, analysis of variance (ANOVA) was used supported Scheffé post-test.

The threshold for statistical significance for all tests was set at $\mathrm{p}<0.05$.

\section{Results}

The performance and the average obtained by the players in Group I at pre-test and post-test are shown in Table 1.

Table 1. Mean and standard deviation of the performance of the subjects in Group I

\begin{tabular}{llll}
\hline Variables & Pre-test $\mathbf{n}(=\mathbf{1 5})$ & post-test $\mathbf{n}(=\mathbf{1 5})$ & P \\
\hline FL $(/$ 20) & $9.5 \pm 3.0$ & $17.1 \pm 2.1$ & $<0.001$ \\
BO $/$ 20) & $9.7 \pm 3.5$ & $19.7 \pm 0.5$ & $<0.001$ \\
EA $(/$ 20) & $8.6 \pm 2.5$ & $16.7 \pm 1.9$ & $<0.001$ \\
SS $(/$ 20) & $0.9 \pm 1.2$ & $13.7 \pm 3.4$ & $<0.001$ \\
\hline
\end{tabular}

FL: flexion of legs; BO: Body orientation; EA: extension of the arms; SS: successful shooting.

The analysis of these results shows that highly significant improvement $(\mathrm{p}<0.001)$ were observed after the cycle, regardless the assessed technical gesture.

As for the experimental group II, and their average scores are presented in Table 2.

Table 2. Mean and standard deviation of the performance of the subjects in Group II

\begin{tabular}{llll}
\hline Variables & Pre-test $\mathbf{n}(=\mathbf{1 5})$ & post-test $\mathbf{n}(=\mathbf{1 5})$ & P \\
\hline FL $(/$ 20) & $5.0 \pm 5.7$ & $15.5 \pm 3.4$ & $<0.001$ \\
BO $(/ \mathbf{2 0})$ & $11.4 \pm 3.4$ & $18.6 \pm 2.1$ & $<0.001$ \\
EA $(/$ 20) & $8.9 \pm 5.6$ & $16.4 \pm 3.6$ & $<0.001$ \\
SS $(/ 20)$ & $1.5 \pm 1.5$ & $9.2 \pm 5.2$ & $<0.001$ \\
\hline
\end{tabular}

FL: flexion of legs; BO: Body orientation; EA: extension of the arms; SS: successful shooting.

The finding was similar for improved performance. However, the flexion of legs (FL) was assimilated better compared to other gestures.

For Group III, performance, and their averages are reported in Table 3.

Table 3. Mean and standard deviation of the performance of the subjects in Group III

\begin{tabular}{llll}
\hline Variables & Pre-test $\mathbf{n}(=\mathbf{1 5})$ & post-test $\mathbf{n}(=\mathbf{1 5})$ & P \\
\hline FL $(/$ 20) & $8.5 \pm 3.9$ & $11.3 \pm 4.1$ & NS \\
BO $/$ 20) & $11.7 \pm 3.3$ & $13.7 \pm 3.0$ & NS \\
EA $(/$ 20) & $12.6 \pm 5.3$ & $11.4 \pm 3.3$ & NS \\
SS $(/$ 20) & $1.7 \pm 1.2$ & $1.6 \pm 1.2$ & .
\end{tabular}

FL: flexion of legs; BO: Body orientation; EA: extension of the arms; SS: successful shooting.

At the end of the cycle, differences observed in scores between the two tests proved statistically insignificant, even if the values of appreciation, during the posttest, were higher for the flexion of legs (FL) and the orientation of the body (OB). Indeed, the differences were minimal, ranging between $17.1 \%$ and $32.9 \%$. Regarding the performance recorded for the extension of the arms (EA) and successful shots (SS), a decrease was noted.

Table 4. Comparative results of the performance of the 3 groups

\begin{tabular}{lllll}
\hline Variables & Group I n(=15) & Group II n(=15) & Group III n(=15) & P \\
\hline Pre-test & & & & \\
FL $(/$ 20) & $9.5 \pm 3.0$ & $5.0 \pm 5.7$ & $8.5 \pm 3.9$ & NS \\
BO $(/$ 20) & $9.7 \pm 3.5$ & $11.4 \pm 3.4$ & $11.7 \pm 3.3$ & NS \\
EA $(/$ 20) & $8.6 \pm 2.5$ & $8.9 \pm 5.6$ & $12.6 \pm 5.3$ & NS \\
SS (/ 20) & $0.9 \pm 1.2$ & $1.5 \pm 1.5$ & $1.7 \pm 1.2$ & NS \\
Post-test & & & & \\
FL $(/$ 20) & $17.1 \pm 2.1$ & $15.5 \pm 3.4$ & $11.3 \pm 4.1$ & $<0.05$ \\
BO $/$ 20) & $19.7 \pm 0.5$ & $18.6 \pm 2.1$ & $13.7 \pm 3.0$ & $<.05$ \\
EA $(/$ 20) & $16.7 \pm 1.9$ & $16.4 \pm 3.6$ & $11.4 \pm 3.3$ & NS \\
SS (/ 20) & $13.7 \pm 3.4$ & $9.2 \pm 5.2$ & $1.6 \pm 1.2$ & $<0.02$ \\
\hline
\end{tabular}


FL: flexion of legs; BO: Body orientation; EA: extension of the arms; SS: successful shooting.

Finally, the comparison of averages obtained at pre-test and post-test between the three (03) groups are shown in Table 4 .

The ANOVA revealed that the performance made by the group I was greater than those of other groups, whatever learned technical gesture.

For The food consumed by group I and II, the period and time table are in table 5.

Table 5. Food consumed by the players of the groups I and II

\begin{tabular}{|c|c|c|c|c|}
\hline Period & Breakfast Food & Lunch Food & Dinner food & \\
\hline \multirow{2}{*}{$\underset{\mathbb{D}}{20}$} & $\begin{array}{llc}\text { Day } & \text { 1: } & \text { Coffee } \\
\text { bread+ butter }\end{array}$ & Day 1: Rice with sea fish sauce+ & $\begin{array}{lllll}\text { Day 1: } & \text { Rice } & \text { with } & \text { chicken+vegetables+ } \\
\text { mandarin } & \end{array}$ & 至. \\
\hline & $\begin{array}{l}\text { Day 2: Lipton Tea Mug+Pain } \\
\text { +orange }\end{array}$ & $\begin{array}{l}\text { Day 2: Cassava with meat sauce+ } \\
\text { orange }\end{array}$ & $\begin{array}{l}\text { Day 2: Foufou with Salted fish in Gnetum+ } \\
\text { orange }\end{array}$ & 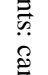 \\
\hline \multirow{2}{*}{ 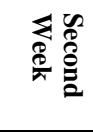 } & $\begin{array}{l}\text { Day 3: Milk Cup+Pain+Ham } \\
+ \text { yellow apple }\end{array}$ & $\begin{array}{l}\text { Day 3: potato+Freshwater Fish }+ \\
\text { vegetable yellow apple }\end{array}$ & $\begin{array}{l}\text { Day 3: pasta }+ \text { minced meat sauce }+ \text { yellow } \\
\text { apple }\end{array}$ & $\stackrel{\vec{c}}{\stackrel{0}{\Sigma}}$ \\
\hline & $\begin{array}{l}\text { Day 4: Coffee }+ \text { Milk Cheese bread }+ \\
\text { pineapple }\end{array}$ & $\begin{array}{l}\text { Day 4: Meat Delicatessen+ cassava } \\
\text { pineapple juice }\end{array}$ & Day 4: Foufou - & $\frac{2}{5}$ \\
\hline \multirow{2}{*}{ 运司: } & $\begin{array}{lcccc}\text { Day 5: } & \text { Milk } \\
+ \text { sardine } & \text { Cup mango }\end{array}$ & $\begin{array}{lcc}\text { Day } & 5: & \text { Rice+tuna } \\
+ \text { mango juice } & \\
\end{array}$ & $\overline{\text { Da }}$ & t. \\
\hline & $\begin{array}{l}\text { Day 6: Pot Cream }+ \text { chocolate } \\
\text { Croissant }+ \text { dessert banana }\end{array}$ & $\begin{array}{l}\text { Day 6: Foufou }+ \text { chicken moambe }+ \\
\text { the orange juice }\end{array}$ & $\begin{array}{l}\text { Day 6: Fish braised }+ \text { yam }+ \text { vegetable }+ \\
\text { banana dessert }\end{array}$ & $\vec{\Delta}$ \\
\hline \multirow{2}{*}{ 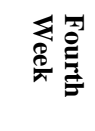 } & Day 7: Lipton Tea+ Fritters + papaya & $\begin{array}{l}\text { Day 7: Rice + Meat Vegetable + } \\
\text { papaya juice }\end{array}$ & $\begin{array}{l}\text { Day 7: Foufou + vegetable }+ \text { with Fish dried } \\
\text { broth +papaya }\end{array}$ & Q \\
\hline & $\begin{array}{l}\text { Day 8: Coffee } \\
\text { mango juice }\end{array}$ & $\begin{array}{l}\text { Day 8: Cassava + fish+ } \\
\text { mango }\end{array}$ & $\begin{array}{l}\text { Day 8: Cassava tuber + smoked meat stock to } \\
\text { Gnetum+ mango juice }\end{array}$ & \\
\hline
\end{tabular}

\section{Discussion}

It is clear from our findings that there are significant differences between the average achieved by the subjects of Group I at pre-test and posttest, on the one hand (Table I), and between the 3 groups on the other hand (Table 4); F=8.94 and $\mathrm{p}<0.05$. The improved performance that we see in subjects of this group is due to the impact of the intervention strategy used.

In this study, these results reveal that mixing the mental repetition of motor skills to his immediate practice is effective for learning. This condition seems to be very favorable for the learner, since the motor image of the ability to learn is doubly reinforced in the memory (Le DEUF, 2002). Similarly, the importance of eating is to be taken into consideration because sports nutrition has proved its merits in energy, vitamin and mineral needs of the sports and fighting against fatigue, injuries, failures and promoting recovery (MAUGHAN RJ, 1999).

Comparing the results of the experimental group II which received food rations during eight (08) sessions as the group I and had mental training on the free throw before and after the meetings, its shows that the differences are also significant at the end of the learning (table 2). In the condition where the subjects in this group are only mental rehearsal, after consuming a balanced meal, progress in shots before and after cannot be noticeable. Here, mental rehearsal and food rations that are used have not favored the development of this team. Perhaps other factors such as fatigue, lack of concentration, and the fear of losing a shot that affected these subjects not to excel positively in successful free throws.

At the end, the comparison of the scores achieved for the control subjects did not reveal significant differences.

These differences are due to the fact that the subjects of this group randomly shot in the basket without specific instructions. They ignored the techniques of shooting. These players participating in any competition, could not get good performance at posttest. At this level, even the effect of the practice made during the pretest did not influence the group.

Our results also confirm the view of Russell (1979). According to this author, mental rehearsal or see assiduously and serious thought helps beginners in a subject to achieve better performance. Besides, Chevalier (1983) confirmed the impact of this strategy when she applied imaging among swimmers by attaching great importance.

Weineck (1986), meanwhile, has demonstrated the effectiveness of mental imagery in sports where physical training time is reduced. In this perspective, the mental training and sports nutrition are used as a complement to warm up or practice and shorten the time of it (time economy). They increase the accuracy, speed of execution of a movement and increase the stability of the body movement. Intakes of carbohydrate, lipid, protein and vitamins allowed a maximum load in the muscle and liver between mental and practical trainings (Coulibaly, 2007).

Thus, to allow food diversity, group I and group II players, received food rations for 2 days in the week for 4 weeks (1 month). This practice has helped offset the intake of carbohydrates, fats, proteins and minerals, essential elements for the realization of the performance. This food intake has filled the average energy expenditure due to physical activity (Basketball) estimated at $500 \mathrm{Kcal}$ per hour (DOROSZ P., 2000). However, the slow digestion of carbohydrates (cereals, 
pulses, pasta) was preferred for storage of carbohydrates in the muscles.

Moreover, Orlick and Partington (1984) also note that the use of mental images has not only a motivational value but also an intrinsic informational value. This is what justifies the significant performance in subjects in the experimental group I.

Finally, Corbillon et al. (2000) show that mental preparation is as important as the physical and technical training to achieve sporting excellence in various disciplines.

In summary, our study confirms once more, in the African context and Congolese or underdevelopment, the effectiveness of the technique of mental imagery and sports nutrition in the development of motor skills in Basketball, particularly in the free throw.

\section{Conclusion}

This study has helped to determine the impact of mental rehearsal and sports nutrition on the learning of the free throw in Congolese Basketball Players.

However, it should be stressed that mental rehearsal is still a very beneficial activity for learners. But this technique alone where physical sensation is nonexistent, does not allow the learner to achieve the best performance, it required to be associated to the practice on the field and a proper diet to achieve sporting excellence.

\section{References}

Burke L. M. (1995). The complete guide is food for sports performances, $2^{\text {nd }}$ edition. Sydney: Allemandunwin.

Chevalier, N. (1983). Mesure de l'activité de l'imagerie chez les nageurs, Canadian of Applied Sport Sciences, 3, 246-253.

Chevalier, N. (1989). L'imagerie dans l'entrainement mental des sportifs: une application en ski de fond. Revue québécoise de Psychologie, 10.

Corbillon, F., \& Fournier, J. (2000). La préparation mentale chez les athlètes d'épreuves combinées de haut niveau, congrès international de SFPS-Paris: INSEP.

Coulibaly, A. T. (2004). Besoins énergétiques des sportifs internationaux maliens en préparation pour les jeux continentaux et européens. Thèse de med. BAMAKO.

Coulibaly, B. (2007). Etude de l'alimentation des basketteurs au cours des préparations précompétitives. Thèse de doctorat de la faculté de médecine, de pharmacie et d'onto-stomatologie de l'université de BAMAKO 2007.

Couture, S. (2013). L'évaluation des connaissances en nutrition des entraineurs et des pratiques alimentaires recommandées à leurs athlètes. Mémoire de maitrise en nutrition, 2013, Québec, Canada.

Deci, E., \& Ryan, R. M. (1980). Self-determination: when mind medicates behaviory. New York: Plenum-Press.

Dorosz, P. (2000). Table des calories, Paris; Maloine, 2000(160).

FAO (2009). Diagnostique du système national de recherche et de vulgarisation agricole du Congo et stratégie de renforcement des capacités pour la dissémination des connaissances et des technologies agricoles. Rome: FAO, 2009

Ledeuff, H. (2002). Entrainement mental du sportif. Paris; éd. Amphora.

Maughan, R. J., \& Burke, L. M. (1999). L'alimentation du footballeur au cours de l'entraînement et de la compétition. Sci Sports, 14, 227-232. http://dx.doi.org/10.1016/S0765-1597(00)88241-6

Orlick, J., \& Partington, J. (1984). Psyched: inner views of winning. Ottawa: Coaching Association of Canada.

Rejeski, W. J., \& Brawley, L. R. (1983). Attribution theory in sport: currents status and new perspective. Journal of Sport Psychology, 5, 77-99. http://dx.doi.org/10.1123/jsp.5.1.77

Russel, B., \& Branch, T. (1979). Second Wind: the memoirs of an opinionated man. New York: Random House.

Ryan, R. M., \& Lackie, W. L. (1986). Competitive and non-competitive performance in relation to achievement motive and manifest anxiety. Journal of Personality and Social Psychology, 1, 342-351. http://dx.doi.org/10.1037/h0021750

Sankale, M., Satge, P., Toury, J., \& Vuylstene, J. (1974). Alimentation et pathologie nutritionnelle en Afrique noir S.A édition 27 rue de Maloine SA Editeur, 27 rue de l'école MED 75006 paris 1974.

Schmidt, R. (1993). Performance et apprentissage moteur Paris: éd. Vigot, Coll. Sport et Enseignement.

Thill, E., \& Mouanda-Mpassi, J. (1988). Les effets de la compétence, ses implantations pratiques. Congrès Franco-allemand des sciences, Strasbourg. 
Traore, Y. S. (2006). Contribution à l'amélioration de l'alimentation des élèves de l'INJS de Bamako, MALI, Thèse de MED Bamako.

Vallerand, R. J., \& Thill, E. (1993). Introduction à la psychologie de la motivation. Québec: Editions Etudes Vivantes.

Weineck, J. (1986). Manuel d'entrainement, Vigot $4^{\text {ème }}$ éd, 1986.

\section{$(\mathrm{cc}) \mathrm{BY}$}

This work is licensed under a Creative Commons Attribution 3.0 License. 